\title{
POLYMORPHISM OF GROWTH HORMONE RECEPTOR GENE AND MYOGENIC FACTOR 5 GENE IN DAIRY CATTLE POPULATIONS
}

Alshamaileh H. S., Kulibaba R. O., National University of Life and Environmental Sciences of Ukraine

Liashenko Yu., Borzova H. S., The Institute of Animal Science NAAS

Investigations of the genetic structure features of the populations of Ukrainian Black-and-White and Red-and-White dairy breeds by polymorphism of growth hormone receptor (GHR) and myogenic factor 5 (MYF5) genes were carried out. AluIpolymorphism in the promoter fragment of the GHR gene and TaqI-polymorphism in the second intron of the MYF5 gene was detected using polymerase chain reaction and restriction analysis (PCR-RFLP). According to the research results, it was shown that the growth hormone receptor and myogenic factor 5 genes in the populations of Ukrainian Black-and-White and Red-and-White dairy breeds are polymorphic. In the population of the Ukrainian Black-and-White dairy breed at the GHR locus, the frequency of the AluI+ allele was 0.61; allele AluI- - 0.39; at the MYF5 locus, the TaqI+ allele frequency was 0.65; allele Taq- - 0.35, respectively. In the population of the Ukrainian Red-and-White dairy breed at the GHR locus, the frequency of the AluI+ allele was 0.54; allele AluI- -0.46; at the MYF5 locus, the TaqI+ allele frequency was 0.64; allele Taq- -0.36, respectively. Both experimental populations for GHR and MYF5 loci are in a genetic equilibrium state according to Hardy-Weinberg, which indicates the absence of microevolutionary changes in the process of their reproduction. There were no significant fluctuations in the genetic structure according to the revealed features of the genotype and allele frequencies distribution. The breeding work that is carried out on both populations does not affect marker alleles (which are described in the work), which is reflected in the features of the genetic-population structure of the experimental groups and their equilibrium state. The features of the distribution of individuals with different genotypes by GHR and MYF5 loci in the populations of both breeds make it possible to carry out further studies to determine the relationship between the identified allelic variants of polymorphic loci with parameters of animal productivity.

Keywords: polymorphism, population, allele, genotype, marker, variability.

УДК:636.2.083:612.017

DOI 10.32900/2312-8402-2021-125-78-91

\section{ПОРІВНЯННЯ РІЗНИХ СИСТЕМ УТРИМАННЯ КОРІВ У ПЕРІОД ТЕПЛОВОГО СТРЕСУ}

\author{
Борщ О. О., к. с.-Г. Н., доцент \\ https://orcid.org/0000-0002-8450-2109 \\ Борщ О. В., к. с.-Г. н., доцент \\ https://orcid.org/0000-0001-5174-1309 \\ Білоцерківський Національний аграрний університет
}

\begin{abstract}
Метою роботи було вивчити вплив високих температур на комфортність утримання корів голштинської породи за різних варіантів безприв'язного утримання. Для проведення досліджень було вибрано три господарства з безприв'язним утриманням корів та різними варіантами рівня комфорту тварин. Перший варіант - безприв'язне утримання у легкозбірному приміщенні. Другий варіант - безприв'язне утримання у легкозбірному приміщенні з вентиляторами
\end{abstract}


та системою зрошування води. Третій варіант - на вигульно-кормових майданчиках з навісами. Протягом добового періоду спостережень визначали основні показники мікроклімату у зоні відпочинку (температуру повітря, відносну вологість, швидкість руху вітру), частоту дихання, оиінку важкості дихання та індекси теплового навантаження. Найкращі показники серед досліджуваних технологій утримання були зафіксовані на фермі з використанням систем зрошення та вентиляиії. У період найвищого теплового стресу (12.00-16.00 год) температура повітря (T) не перевищувала $29,05 \pm 0,50{ }^{\circ} \mathrm{C}$, частота дихання -

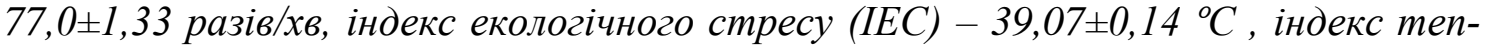

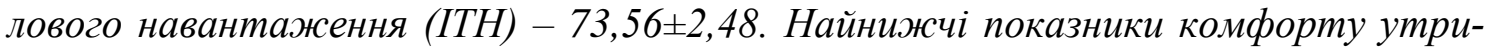
мання були у легкозбірному приміщенні: $T-31,1 \pm 2,24{ }^{\circ} \mathrm{C}$, частота дихальних

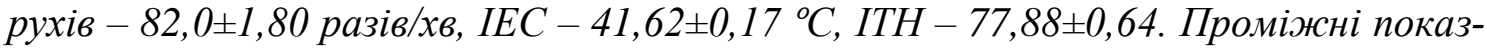
ники були за утримання на кормовому майданчику: $T-30,3 \pm 2,31{ }^{\circ} \mathrm{C}$, частота ди-

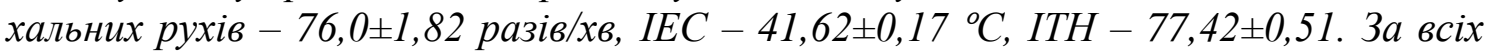
варіантів утримання корів підвищення температури до середньодобових $+27,7$ ${ }^{\circ}$ С стало значним стрес-фактором, який суттєво вплинув на динаміку частоти дихання, оцінку важкості дихання, значення IEC і ITH. Встановлено, щуо за утримання корів у приміщеннях з використанням систем зрошення $і$ вентиляції та на вигульних майданчиках показники ТВI, частоти та важкості дихання у період максимального температурного навантаження (12.00-16.00 год) були нижчими, чим за утримання у легкозбірному приміщенні.

Ключові слова: молочні корови, технологія утримання, температура, тепловий стрес, комфорт, важкість дихання.

В останнє десятиліття продовжується тенденція до глобального потепління, котре вже суттєво відчувається на регіональних та місцевий рівнях [1]. Для країн Свропи у найближчі 3-5 років прогнозується підвищення температури у всі сезони року [2]. Регіональні кліматичні моделі прогнозують сильні потепління у значній частині північно-східної Свропи що особливо відчувається взимку, а в південній та південно-західній Європі влітку. Разом з підвищенням середньорічної температури змінюються показники відносної вологості повітря, кількості атмосферних опадів, а також напрям і сила вітру. Сезонні зрушення та зміни частоти та інтенсивності погодних показників впливають на багато економічних явищ галузі сільського господарства [3]. Очікується, що приблизно 26 \% усіх збитків та втрат, пов'язаних із змінами клімату та погодними умовами припадають на такі сектори сільського господарства, як рослинництво, тваринництво, рибальство, аквакультура та лісове господарство [4].

Однією з основних проблем при виробництві молока поряд із тривалістю продуктивного використання, відтворенням, кількісним і якісним складом молочного жиру та білка [5, 6] є температурні стреси [7]. Термонейтральною, тобто такою, яка не впливає на комфорт добробут і продуктивність для організму молочної худоби є температура у діапазоні від -5 до $25^{\circ} \mathrm{C}[8,9]$. В умовах термонейтральної температури організм витрачає мінімальну кількість енергії на підтримку життя або рівноваги із зовнішнім середовищем [10]. Вплив температури на організм корів варто розглядати в поєднанні з такими факторами як: атмосферний тиск, відносна вологість повітря, сонячна інсоляція, швидкість руху вітру, кількість опадів, котрі підвищують або понижують її відчуття $[11,12]$.

Основним заходом котрий покращує добробут корів у стресових кліматичних умовах є поліпшення умов утримання тварин в різні пори року. Важливе значення у подоланні кліматичного стресу та його наслідків мають різноманітні 
планувальні, конструкційні та технічні рішення приміщень і споруд для утримання худоби [13-15]. Використання світлових штор (з елементами утеплення взимку), світло-аераційного гребеня, фідлотів з навісами, систем зрошення та вентиляції, двокамерних водяних матраців для відпочинку корів, приміщень $з$ системами крос-вентиляції та даху з сендвіч-панелями зменшують кліматичний стрес, дозволяють стабілізувати продуктивність корів та збільшити тривалість їхнього відпочинку [16-18]. На теплову чутливість молочної худоби поряд із природнокліматичною зоною, показниками мікроклімату і генетичними ознаками мають i технологія утримання тварин та конструкційні особливості приміщень [19, 20].

Метою досліджень було вивчення впливу високих температур на комфортність утримання корів голштинської породи за різних варіантів безприв'язного утримання.

Матеріали та методи досліджень. Дослідження проводили у період 3 02.07-12.07 2018 року (183-194 дні року) у центральній частині України

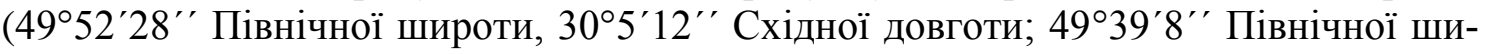

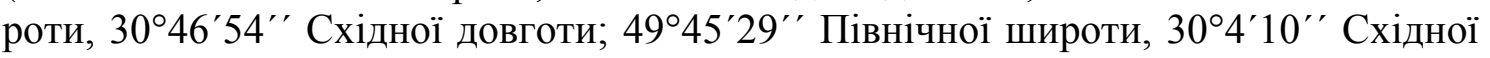
довготи) в період високотемпературного навантаження. Середньодобова температура в цей період становила $+27,7^{\circ} \mathrm{C}$.

Для проведення досліджень було вибрано три господарства 3 безприв'язним утриманням корів та різними варіантами рівня комфорту тварин. Перший варіант $(\mathrm{T}-1)$ - безприв'язне утримання у легкозбірному приміщенні $(150 \times 40 \times 10$ м). Другий варіант $(\mathrm{T}-2)$ безприв'язне утримання у легкозбірному приміщенні з вентиляторами та системою зрошування води $(100 \times 32 \times 8$ м). Системи вентиляції та зрошування працюють 3 періодичністю 0,5 та 1 год у період 3 12.00 до 16.00. Третій варіант (Т-3) - на вигульно-кормових майданчиках 3 навісами $\left(72 \times 25\right.$ м; площа вигульного майданчика $20 \mathrm{~m}^{2}$ на 1 голову, в т.ч. площа навісу $5 \mathrm{~m}^{2}$ на голову).

Матеріалом для досліджень були корови голштинської породи другої лактації у період максимальної продуктивності (2-3 місяць лактації). У кожному із господарств було сформовано групи корів по 15 голів в кожній.

Температуру повітря і відносну вологість в приміщеннях визначали комбінованим цифровим приладом Velleman, модель DVM401 (Бельгія). Швидкість вітру в приміщеннях визначали цифровим анемометром AZ, модель AZ8919 (Тайвань).

Температурно-вологісний індекс (ТВI) розраховували згідно з методикою Dikmen \& Hansen, 2009 [21].

$$
\mathrm{TBI}=(1.8 \times \mathrm{T}+32)-(0.55-0.0055 \times \mathrm{BB}) \times(1.8 \times \mathrm{T}-26.8), \quad(1)
$$

де Т - температура повітря, ${ }^{\circ} \mathrm{C}$; ВВ - Відносна вологість повітря, $\%$.

TВI було розподілено на 3 категоріі: 1) 66-71 - нормальний; 2) 72-79 тривожний; 3) 80 і більше - небезпечний.

Індекс екологічного стресу (IEC) розраховували згідно з методикою Moran et al., 2001 [22]. Індекс теплового навантаження (ITH) розраховували згідно з методикою Gaughan et al., 2002 [23].

$\mathrm{ITH}=33.2+0.2 \times \mathrm{BB}+1.2 \times \mathrm{T}-(0.82 \times \amalg B)^{0.1}-\log \left(0.4 \times \mathrm{WB}^{2}+0.0001\right)$, (2)

де ШВ - швидкість руху вітру $(\mathrm{m} / \mathrm{c})$.

IEC було розподілено на 4 категорії: 1) термонейтральні кондиції, коли IEC становить $<70.0 ; 2)$ вологі кондиції, коли IЕC від 70.1 до 77.0; 3) жаркі кондиції, коли IEC від 77.1 до 86.0; 4) дуже жаркі кондиції, коли IEC від 86.0 і більше.

Важкість дихання визначали за шкалою від 0 до 4,5 балів Gaughan et al., 2008 [24]. Де: 0 - рівне дихання, без ознак задихання; 1 - короткотривале приско- 
рене дихання, рот закритий, на носовому дзеркалі та щелепах немає слідів слини, ледь помітні рухи грудної клітки; 2 - прискорене дихання, на носовому дзеркалі та щелепах 3'являється слина, рот закритий; 2,5 - важке дихання, час від часу 3 відкритим ротом, язик не висунутий на зовні; 3 - відкритий рот, слиновиділення надмірне, шия витягнута, голова піднята вгору; 3,5 - теж що і 3 бали, але 3 короткотривалим злегка висунутим язиком (іноді повністю висунутим); 4 - відкритий рот з висунутим протягом тривалого часу язиком, надмірне слиновиділення, голова піднята вгору, шия витягнута; 4,5 - голова опущена донизу, важке дихання 3 частим коливанням в боках (реберна частина), слиновиділення відсутнє.

Матеріали досліджень обробляли методом варіаційної статистики на основі розрахунку середнього арифметичного (M) та середньоквадратичної похибки (m) [25].

Результати досліджень. За технології утримання корів у легкозбірному приміщенні (T-1) спостерігали дещо вищі середньодобові показники температури повітря порівняно з іншими варіантами утримання (рис. 1). Так, у період з 12.00 по 16.00 год температура була у діапазоні $31,1 \pm 2,24{ }^{\circ} \mathrm{C}$, а найнижче значення $23,0 \pm 0,4{ }^{\circ} \mathrm{C}$ було відмічено тільки о 04.00 годині. У приміщенні з використанням систем зрошення та вентиляції (T-2) температура у періоди найвищого теплового стресу не перевищувала $29,0 \pm 0,5^{\circ} \mathrm{C}$, а у нічний час $00.00-04.00$ год становила $21,0 \pm 0,3{ }^{\circ} \mathrm{C}$. При утриманні на вигульно-кормових майданчиках 3 навісами $(\mathrm{T}-3)$ спостерігали найбільше середньодобове коливання температури повітря в $13{ }^{\circ} \mathrm{C}$. В період з 02.00-04.00 год температура становила 20,4 $\pm 0,70{ }^{\circ} \mathrm{C}$, а 312.00 по 16.00 год $-30,3 \pm 2,31^{\circ} \mathrm{C}$.

Щодо відносної вологості повітря, то за всіх варіантів утримання спостерігали поступове зниження після 12.00 год з подальшим незначним підвищенням о 20.00 год. Найвище середньодобове значення відносної вологості спостерігали за технології утримання з використанням системи зрошення та вентиляції (Т-2) $55,08 \pm 4,11 \%$, що на 1,88 та 3,33\% вище, ніж за утримання в легкозбірному приміщенні та на вигульно-кормових майданчиках відповідно.

Згідно з даними Hulsen, 2006 [26] оптимальний показник швидкості руху вітру при утриманні молочної худоби не повинен перевищувати $0,7 \mathrm{~m} / \mathrm{c}$ (або 2,52 км/год). Результати наших досліджень показали, що найнижча середня добова швидкість руху вітру була за утримання корів у легкозбірному приміщенні $(\mathrm{T}-1)-0,57 \pm 0,01 \mathrm{~m} / \mathrm{c}$ (або 2,08 км/год). За технології утримання з використанням систем зрошення та вентиляції (T-2) спостерігали дещо вищий середній показник

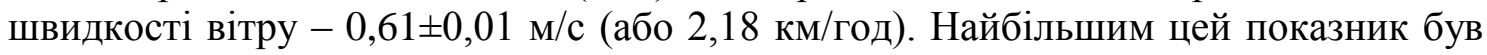
за утримання на вигульно-кормових майданчиках 3 навісами (Т-3) 0,64 $\pm 0,02$ м/с. Це пояснюється тим, що територія майданчику знаходиться на відкритому просторі та на ній немає жодних споруд крім навісів.

Значення температурно-вологісного індексу (ТНI) вказує наскільки поєднання показників температури повітря та відносної вологості може впливати на тепловий стрес тварин [7]. Встановлено, що за утримання корів у легкозбірному приміщенні (Т-1) показники ТНІ суттєво змінювались протягом доби. У період 3 00.00-06.00 тепловий стрес був відсутній $(70,43 \pm 1,28)$, у період з 08.00-12.00 спостерігали помірний тепловий стрес $(74,96 \pm 1,76)$, а починаючи з 14.00 по 18.00 був сильний тепловий стрес $(80,34 \pm 0,40)$. Результати досліджень за технології з використанням систем зрошення та вентиляції (Т-2) і на вигульно-кормових майданчиках з навісами (Т-3) мали ідентичний характер. За обох варіантів утримання у період з 00.00-08.00 год тепловий стрес був відсутній $(69,20 \pm 1,54$ та $67,87 \pm 1,83)$, а

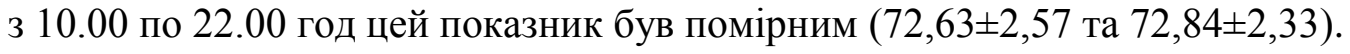




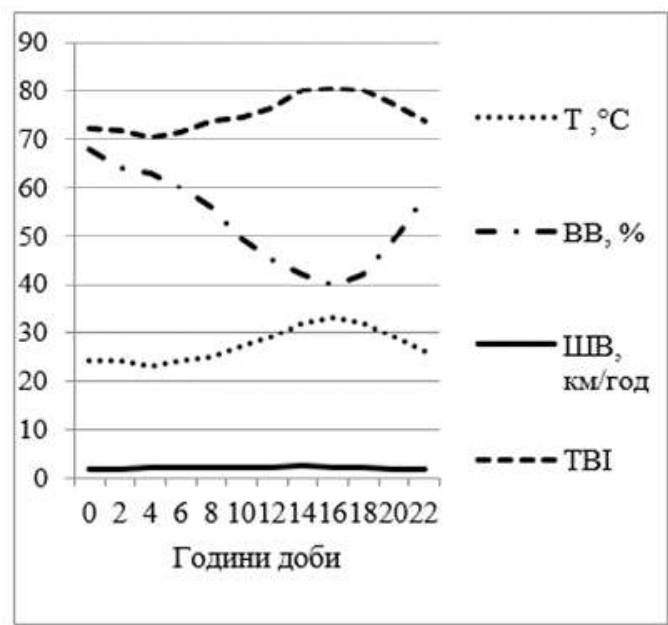

a)

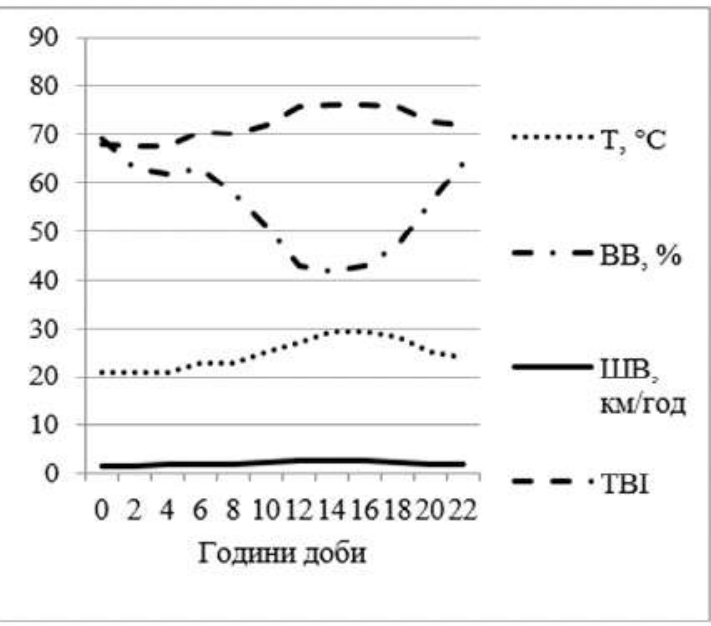

б)

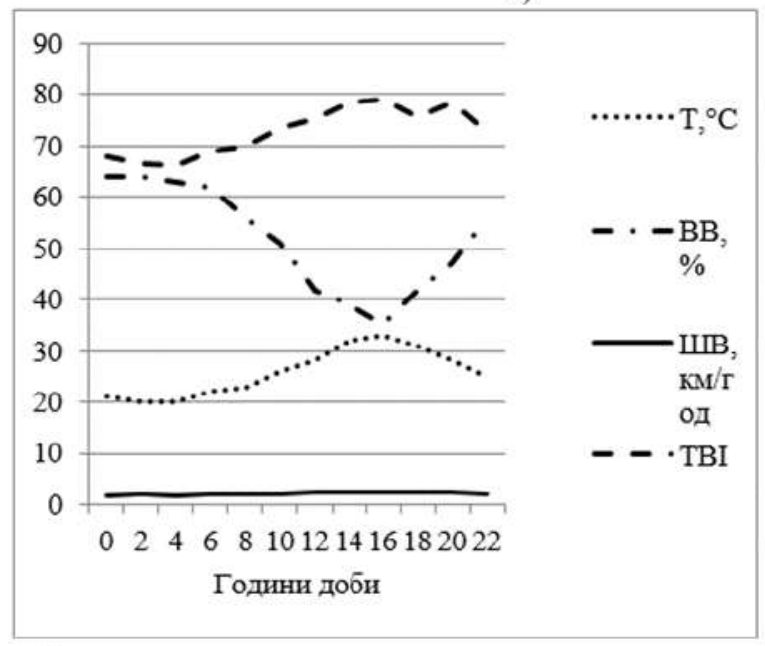

B)

Рис. 1 Середня погодинна температура повітря (Т), відносна вологість (ВВ), швидкість вітру (ШВ) і температурно-вологісний індекс (ТВI) при різних варіантах утримання: а) T-1, б) T-2, в) T-3

Високі показники температури повітря та відносної вологості поряд із втратою продуктивності та погіршенням добробуту тварин впливають і на частоту дихання [20]. Частота дихання впливає на біоенергетичні та гематологічні показники молочної худоби, а також на транспортування кисню до життєвоважливих органів та тканин. Результати досліджень показали, що кількість дихальних рухів/хвилину за всіх варіантів утримання поступово збільшувалась починаючи 3 10.00, а зменшення спостерігали після 16.00 (рис. 2).

Найбільша частота дихання спостерігалась у період з 12.00 по 16.00. За утримання на вигульних майданчиках з навісами $(\mathrm{T}-3)$ частота дихальних рухів у цей період становила $76,0 \pm 1,82$ разів/хв 3 піком у 79,0 01,55 разів/хв о 14.00 . У приміщенні з системою зрошення та вентиляцією (Т-2) в найбільш спекотний період доби спостерігали наступні показники частоти дихання: 12.00-14.00 $77,0 \pm 1,33 ; 16.00-75,0 \pm 1,18$ разів/хв. Дещо вищі показники інтенсивності дихання як протягом доби, так і в період найвищого температурного навантаження спостерігали за утримання у легкозбірному приміщенні (Т-1). Так, о 12.00 кількість

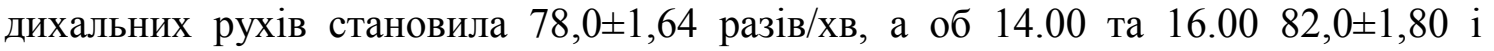
$77,0 \pm 1,53$ разів/хв відповідно. 


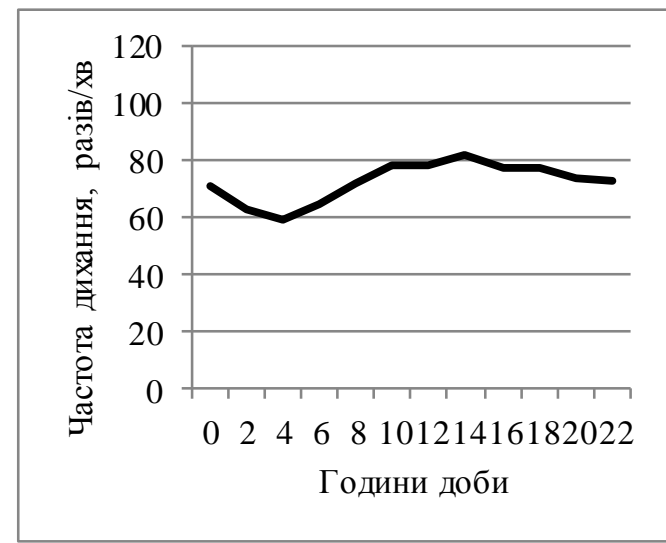

a)

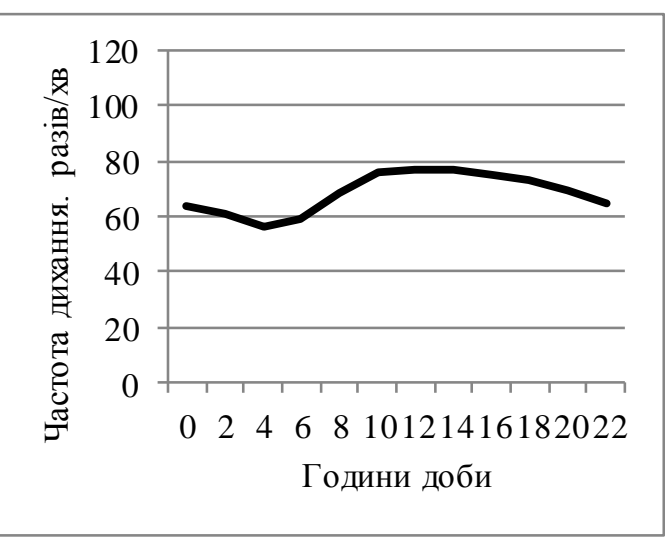

б)

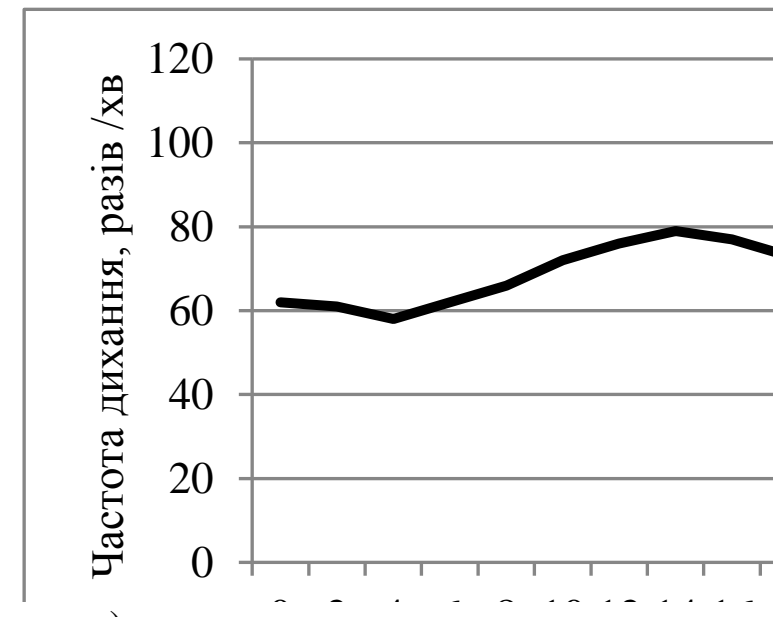

в)

Рис. 2 Середня погодинна частота дихання при різних варіантах утримання: а) $\mathbf{T}-1$, б) $\mathbf{T}-2$, в) $\mathbf{T}-3$

Одним із найважливіших показників, що характеризує комфорт утримання молочної худоби у періоди високотемпературного навантаження є важкість дихання $[24,25]$. Результати спостережень показали, що за всіх варіантів утримання протягом добового періоду не спостерігалось критичних показників важкості дихання (рис. 3).

Загальна оцінка по кожній із груп навіть у пік температурного навантаження (12.00-16.00 год) не перевищувала 3,0土0,1 бали. Найбільш оптимальну криву важкості дихання спостерігали за утримання на вигульних майданчиках 3 навісами (T-3) та у приміщенні з штучним регулюванням мікроклімату (T-2). 3а таких варіантів утримання найвищий бал важкості дихання спостерігали у період

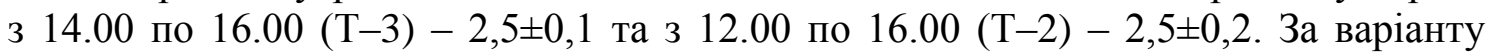
утримання корів у легкозбірному приміщенні (T-1) спостерігали дещо вищі середні бали важкості дихання, а середній бал по групі у період з 12.00 по 16.00 год

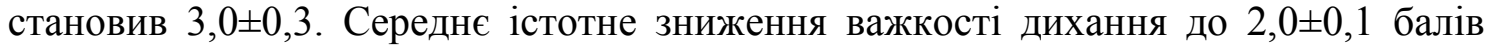
спостерігали лише після 18.00 . 


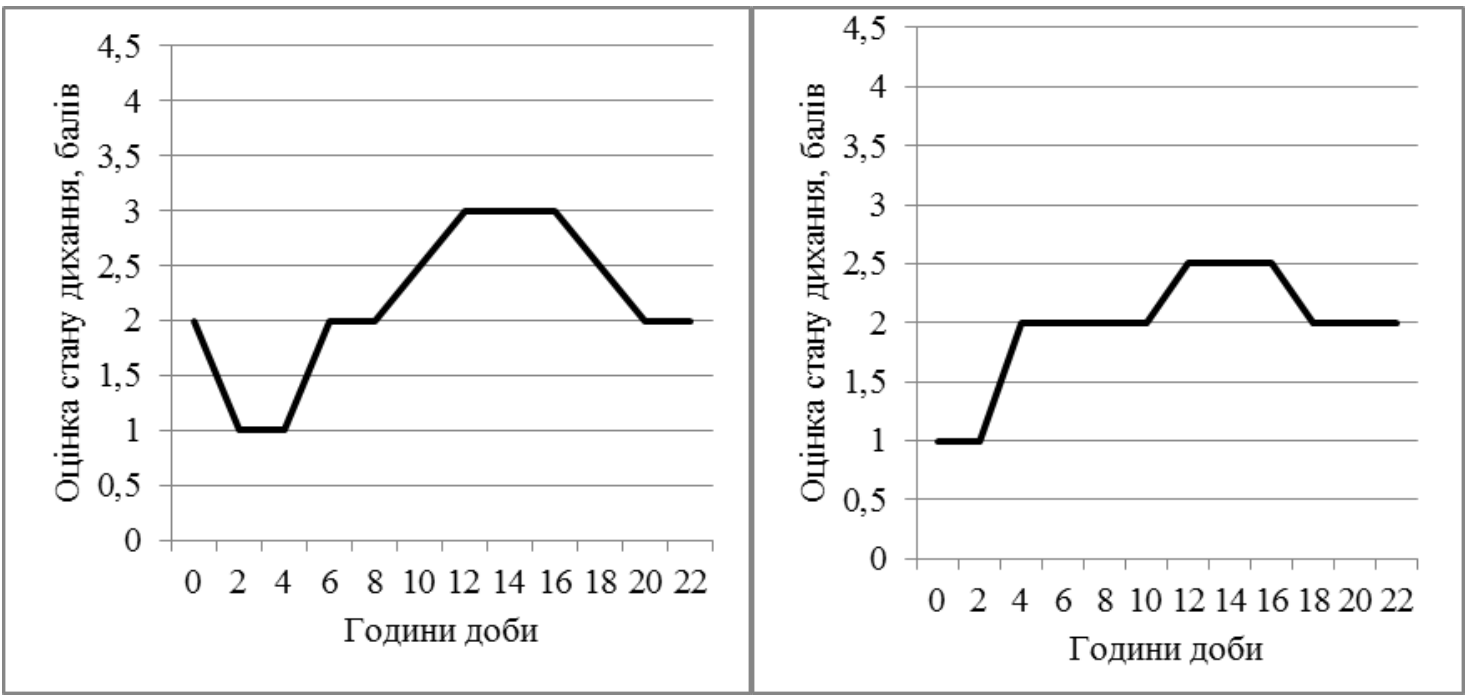

a)

б)

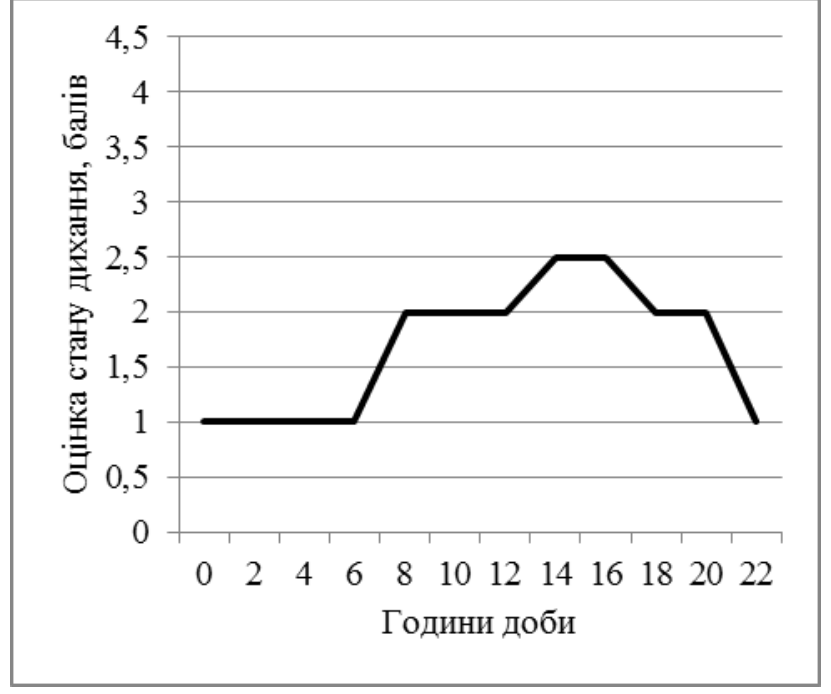

B)

Рис. 3 Середня погодинна оцінка стану дихання при різних варіантах утримання: а) $\mathrm{T}-1$, б) $\mathrm{T}-2$, в) $\mathrm{T}-3$

Для більш повноцінного вивчення впливу високих температур на комфорт корів за різних варіантів утримання використовували індекс екологічного стреса IEC та індекс теплового навантаження ITH (рис. 4).

Добова динаміка зміни IEC за всіх варіантів утримання була однаковою. За технологій утримання корів у легкозбірному приміщенні (T-1) та на вигульнокормових майданчиках (T-3) у період з 14.00 по 16.00 год значення IEC перевищувало $40{ }^{\circ} \mathrm{C}$ і становило $41,62 \pm 0,17$ та $40,79 \pm 0,29{ }^{\circ} \mathrm{C}$ відповідно. При цьому за технології утримання 3 використанням систем зрошення і вентиляції у аналогічний період ці показники не перевищували $39,07 \pm 0,14{ }^{\circ} \mathrm{C}$. Значення ITH за утримання корів у легкозбірному приміщенні $(\mathrm{T}-1)$ у різні періоди доби відрізнялось. У період з 00.00 по 12.00 год було в діапазоні 75,79 $\pm 0,59$, що відноситься до

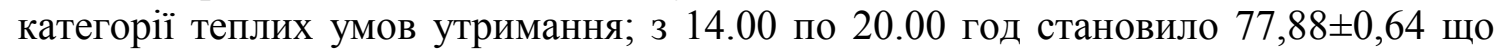
відноситься до спекотних умов утримання. Протягом доби у приміщенні з використанням систем зрошення і вентиляції (T-2) значення ITH було в межах категорії теплих умов утримання і становило - 73,56 2,48 . Щодо утримання на вигульно-кормових майданчиках (Т-3), то тут значення ITH змінювалось протягом доби. 
У період з 02.00 по 04.00 год становило $69,46 \pm 0,44$, що відноситься до термонейт-

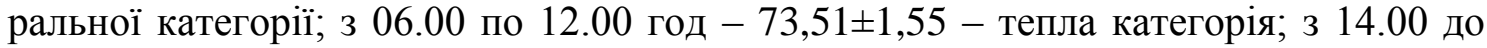
18.00 год - 77,42 $\pm 0,51$ - спекотна категорія.

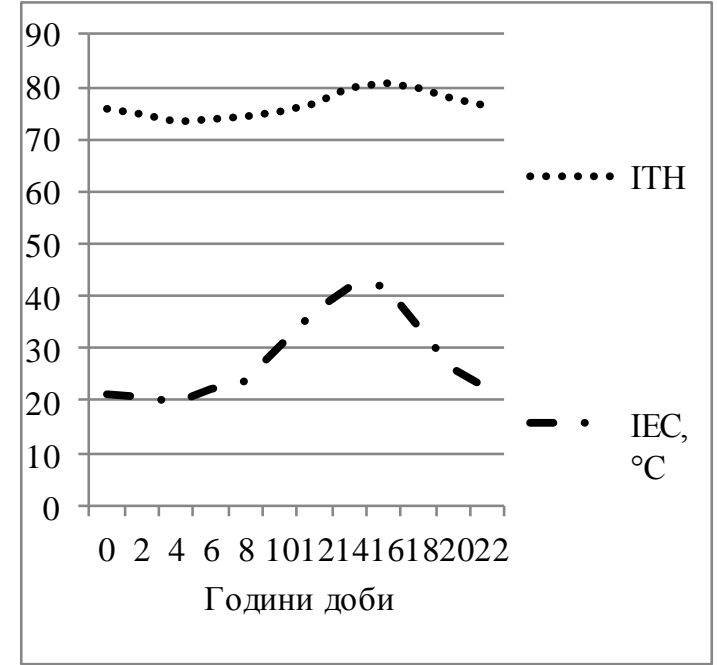

a)

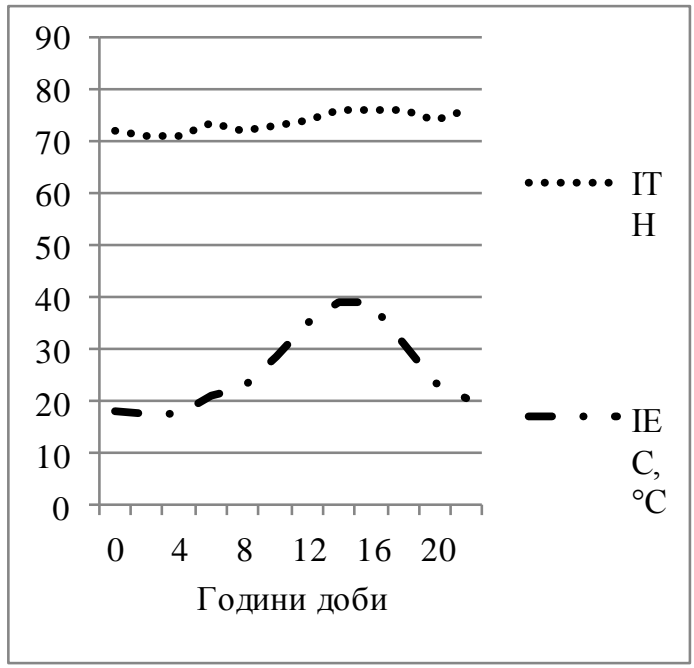

б)

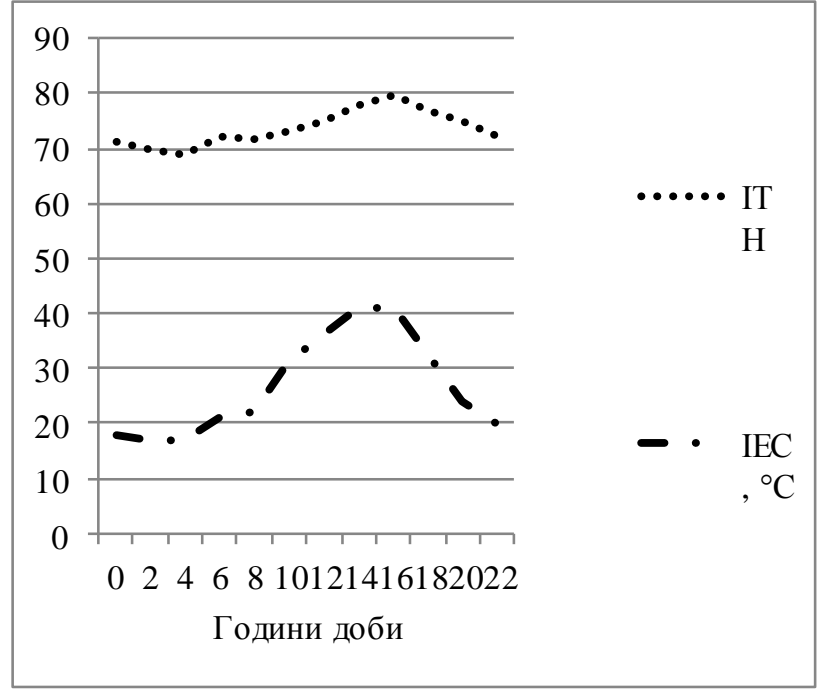

B)

Рuc. 4 Середні погодинні показники індексу екологічного стресу (IEC) та індексу теплового навантаження (ITH) при різних варіантах утримання: a) $\mathbf{T}-1$, б) $\mathbf{T}-2$, в) $\mathrm{T}-3$

\section{Висновки:}

1. За всіх варіантів утримання корів підвищення температури до середньодобових $+27,7^{\circ} \mathrm{C}$ стало значним стрес-фактором, який суттєво вплинув на динаміку частоти дихання, оцінку важкості дихання, значення IEC і ITH.

2. Встановлено, що за утримання корів у приміщеннях з використанням систем зрошення і вентиляції та на вигульних майданчиках показники TBI, частоти та важкості дихання у період максимального температурного навантаження (12.00-16.00 год) були нижчими, чим за утримання у легкозбірному приміщенні.

3. Використання систем регулювання мікроклімату дозволило зменшити температуру у період з 12.00 по 16.00 год на $2-4{ }^{\circ} \mathrm{C}$ порівняно 3 утриманням у легкозбірному приміщенні та на $1-4{ }^{\circ} \mathrm{C}$ порівняно $з$ утриманням на вигульних 
майданчиках. Тривалість термонейтрального періоду за такої системи утримання збільшилась на 2,3 та 1,7 год, ніж за утримання в легкозбірному приміщенні та на вигульному майданчику.

\section{Бібліографічний список}

1. WMO: WMO Statement on the state of the global climate in 2017. WMO№.1212, Publications Board World Meteorological Organization (WMO), World Meteorological Organization, Geneva, Switzerland, 2018.

2. Kjellström E., Nikulin G., Strandberg G., Christensen O. B., Jacob D., Keuler K., Lenderink G., van Meijgaard E., Schär C., Somot S., Sørland S. L., Teichmann C., Vautard R. European climate change at global mean temperature increases of 1.5 and $2{ }^{\circ} \mathrm{C}$ above pre-industrial conditions as simulated by the EURO-CORDEX regional climate models. Earth System Dynamics. 2018. Vol. 9. P. 459-478. https://doi.org/10.5194/esd-9-459-2018

3. Nardone A., Ronchi B., Lacetera N., Ranieri M.S., Bernabucci U. Effects of climate changes on animal production and sustainability of livestock systems, Livestock Science. 2010. Vol. 130. P. 57-69. DOI: 10.1016/j.livsci.2010.02.011

4. Food and Agriculture Organization of the United Nations (FAO): The Impact of Disasters on Agriculture - Assessing the information gap, available at: http://www.fao.org/3/a-i7279e.pdf, 2017.

5. Borshch O. O., Borshch O. V., Kosior L. T., Pirova L. V., Lastovska I. O. Influence of various litter materials and premises characteristics on the comfort and behavior of cows. Ukrainian Journal of Ecology. 2017. Vol. 7 (4). P. 529-535. DOI: 10.15421/2017_156

6. Borshch O. O., Borshch O. V., Donchenko T. A., Kosior L. T., Pirova L. V. Influence of low temperatures on behavior, productivity and bioenergy parameters of dairy cows kept in cubicle stalls and deep litter system. Ukrainian Journal of Ecology. 2017. Vol. 7 (3). P. 73-77. DOI:10.15421/2017_51

7. Borshch A. A., Ruban S., Borshch A. V., Babenko O. Effect of three bedding materials on the microclimate conditions, cows behavior and milk yield. Polish Journal of Natural Sciences. 2019. Vol. 34. P. 19-31.

8. Ruban S., Borshch O. O., Borshch O. V., Orischuk O., Balatskiy Y., Fedorchenko M., Kachan A., Zlochevskiy M. Respiration rate, breathing condition and productivity of dairy cows. Animal Science Papers and Reports., 2020. Vol. 38 (1). P. 61-72.

9. Hempel S., Menz C., Pinto S., Galán E., Janke D., Estellés F., MüschnerSiemens T., Wang X., Heinicke J., Zhang G., Amon B., del Prado A., Amon T. Heat stress risk in European dairy cattle husbandry under different climate change scenarios - uncertainties and potential impacts. Earth System Dynamics. 2019. Vol. 10. P. 859884. https://doi.org/10.5194/esd-10-859-2019

10. Borshch O. O., Gutyj B. V., Sobolev O. I., Borshch O. V., Ruban S. Yu., Bilkevich V. V., Dutka V. R., Chernenko O. M., Zhelavskyi M. M., Nahirniak T. Adaptation strategy of different cow genotypes to the voluntary milking system. Ukrainian Journal of Ecology. Vol. 10 (1). P. 145-150. DOI: 10.15421/2020_23.

11. Рубан С. Ю., Борщ О. В., Борщ О. О. Сучасні технології виробництва молока (особливості експлуатації, технологічні рішення, ескізні проекти) Харків : ФОП Бровін О. В., 2017. 172 с.

12. Borshch O. O., Gutyj B. V., Borshch O. V., Sobolev O. I., Chernyuk S. V., Rudenko O. P., Kalyn B. M., Lytvyn N. A., Savchuk L. B., Kit L. P., Nahirniak T. B., 
Kropyvka S. I., Pundyak T. O. Environmental pollution caused by the manure storage. Ukrainian Journal of Ecology. 2020. Vol. 10 (3). P. 110-114. doi: 10.15421/2020_142

13. Даншин В. О., Рубан С. Ю., Федота О. М., Мітіогло Л. М., Борщ О. О. Оцінка племінної цінності бугаїв-плідників молочних порід. Збірник наукових праць БНАУ «Технологія виробництвва $і$ переробки продукції тваринництва». 2016. № 2. С. 110-116.

14. Рубан С. Ю., Борщ О. О., Федота О. М., Борщ О. В. Сучасні методи селекції у тваринництві: навч. посіб. з оцінки екстер'єру в молочному скотарстві. Київ: ЦП «Компринт», 2018. 149 с.

15. Борщ О. В. Особливості доїння корів на роботизованій установці. Збірник наукових прачь Білочерківського наи. аграр. ун-ту. Серія: «Технологія виробництва і переробки продукції тваринництва». Біла Церква, 2014. № 2 (112). C. 131-135.

16. Dikmen S. J., Hansen S. Is the temperature-humidity index the best indicator of heat stress in lactating dairy cows in a subtropical environment? Journal of Dairy Science. 2009. Vol. 92. P. 109-116. DOI: 10.3168/jds.2008-1370.

17. Menconi M. E., Grohmann D. Model integrated of life-cycle costing and dynamic thermal simulation (mild) to evaluate roof insulation materials for existing livestock buildings. Energy and Buildings, 2014. Vol. 81. P. 48-58. DOI:10.1016/j.enbuild.2014.06.005

18. Smith J. F., Bradford B. J., Harner J. P., Potts J. C., Allen J. D., Overton M. W., Ortiz X. A., Collier R. J. Short communication: Effect of cross ventilation with or without evaporative pads on core body temperature and resting time of lactating cows. Journal of Dairy Science. 2016. Vol. 99. P. 1495-1500. DOI: $10.3168 /$ jds.2015-9624

19. Gebremedhin K. G., Wu B., Perano K. Modeling conductive cooling for thermally stressed dairy cows. Journal of Thermal Biology. 2016. Vol. 56. P. 91-99. DOI:10.1016/ j.jtherbio.2016.01.004

20. Borshch O. O., Ruban S. Yu., Gutyj B. V., Borshch O. V., Sobolev O. I., Kosior L. T., Fedorchenko M. M., Kirii A. A., Pivtorak Y. I., Salamakha I. Yu., Hordiichuk N. M., Hordiichuk L.M., Kamratska O. I., Denkovich B. S. Comfort and cow behavior during periods of intense precipitation. Ukrainian Journal of Ecology, 2020. № 10(6). 98-102. DOI: 10.15421/2020_265

21. Dikmen S. J., Hansen S. Is the temperature-humidity index the best indicator of heat stress in lactating dairy cows in a subtropical environment? Journal of Dairy Science. 2009. Vol. 92. P. 109-116. DOI: 10.3168/jds.2008-1370.

22. Moran D. S., Pandolf K. B., Shapiro Y. An environmental stress index (ESI) as a substitute for the wet bulb globe temperature (WBGT). Journal of Thermal Biology. 2001. Vol. 26. P. 427-431. DOI: 10.1016/S0306-4565(01)00055-9

23. Gaughan J. B., Mader T. L., Holt S. M., Hahn G. L., Young B. A. Review of current assessment of cattle and microclimate during periods of high heat load. Animal Production of Australia. 2002. Vol. 24. P. 77-80.

24. Gaughan J. B., Mader T. L., Holt S. M., Lisle A. A new heat load index for feedlot cattle. Faculty Papers and Publications in Animal Science. 2008. Vol. 1(1). P. 226-234.

25. Вацький В. Ф. Алгоритми біометрії: метод. рек. Полтава, 2005. 19 с.

26. Hulsen J. Cow signals. A practical guide for dairy farm management. 2006. $95 \mathrm{p}$. 


\section{References}

1. WMO: WMO Statement on the state of the global climate in 2017 (2018). WMO-No.1212, Publications Board World Meteorological Organization (WMO), World Meteorological Organization, Geneva, Switzerland.

2. Kjellström, E., Nikulin, G., Strandberg, G., Christensen, O. B., Jacob, D., Keuler, K., Lenderink, G., van Meijgaard, E., Schär, C., Somot, S., Sørland, S. L., Teichmann, C., \& Vautard, R. (2018). European climate change at global mean temperature increases of 1.5 and $2{ }^{\circ} \mathrm{C}$ above pre-industrial conditions as simulated by the EURO-CORDEX regional climate models. Earth System Dynamics, 9, P. 459-478. https://doi.org/10.5194/esd-9-459-2018

3. Nardone, A., Ronchi, B., Lacetera, N., Ranieri, M. S., \& Bernabucci, U. (2010). Effects of climate changes on animal production and sustainability of livestock systems. Livestock Science, 130, 57-69. DOI: 10.1016/j.livsci.2010.02.011

4. Food and Agriculture Organization of the United Nations (FAO): The Impact of Disasters on Agriculture - Assessing the information gap, available at: http://www.fao.org/3/a-i7279e.pdf, 2017.

5. Borshch, O. O., Borshch, O. V., Kosior, L. T., Pirova, L. V., \& Lastovska, I. O. (2017). Influence of various litter materials and premises characteristics on the comfort and behavior of cows. Ukrainian Journal of Ecology, 7 (4), 529-535. DOI: $10.15421 / 2017 \_156$

6. Borshch, O. O., Borshch, O. V., Donchenko, T. A., Kosior, L. T., \& Pirova, L. V. (2017). Influence of low temperatures on behavior, productivity and bioenergy parameters of dairy cows kept in cubicle stalls and deep litter system. Ukrainian Journal of Ecology, 7 (3), 73-77. DOI: 10.15421/2017_51

7. Borshch, A. A., Ruban, S., Borshch, A. V., \& Babenko, O. (2019). Effect of three bedding materials on the microclimate conditions, cows behavior and milk yield. Polish Journal of Natural Sciences, 34, 19-31.

8. Ruban, S., Borshch, O. O., Borshch, O. V., Orischuk, O., Balatskiy, Y., Fedorchenko, M., Kachan, A., \& Zlochevskiy, M. (2020). Respiration rate, breathing condition and productivity of dairy cows. Animal Science Papers and Reports, 38 (1), $61-72$.

9. Hempel, S., Menz, C., Pinto, S., Galán, E., Janke, D., Estellés, F., MüschnerSiemens, T., Wang, X., Heinicke, J., Zhang, G., Amon, B., del Prado, A., \& Amon, T. (2019). Heat stress risk in European dairy cattle husbandry under different climate change scenarios - uncertainties and potential impacts. Earth System Dynamics, 10, 859-884. https://doi.org/10.5194/esd-10-859-2019

10. Borshch, O. O., Gutyj, B. V., Sobolev, O. I., Borshch, O. V., Ruban, S. Yu., Bilkevich, V. V., Dutka, V. R., Chernenko, O. M., Zhelavskyi, M. M., \& Nahirniak, T. Adaptation strategy of different cow genotypes to the voluntary milking system. Ukrainian Journal of Ecology, 10 (1), 145-150. DOI: 10.15421/2020_23.

11. Ruban, S. Yu., Borshch, O. V., \& Borshch, O. O. (2017). Suchasni tekhnolohiyi vyrobnytstva moloka. (osoblyvosti ekspluatatsiyi, tekhnolohichni rishennya, eskizni proekty) [Modern milk production technologies. (peculiarities of operation, technological decisions, sketch designs)]. Kharkiv: STYLIZDAT [in Ukrainian].

12. Borshch, O. O., Gutyj, B. V., Borshch, O. V., Sobolev, O. I., Chernyuk, S. V., Rudenko, O. P., Kalyn, B. M., Lytvyn, N. A., Savchuk, L. B., Kit, L. P., Nahirniak, T. B., Kropyvka, S. I., \& Pundyak, T. O. (2020). Environmental pollution caused by the manure storage. Ukrainian Journal of Ecology, 10(3), P. 110-114. DOI: 10.15421/2020_142 
13. Danshy`n, V. O., Ruban, S. Yu., Fedota, O. M., Mitioglo, L. M., \& Borshch, O. O. (2016). Ocinka pleminnoyi cinnosti bugayiv-plidny`kiv molochny`x porid. [Assessment of the breeding value of dairy bulls.] Zbirny` $k$ naukovy`x pracz` $B N A U$ «Texnologiya vy robny 'cztva i pererobky 'produkciyi tvary nny 'cztva»-Collection of scientific works of BNAU "Technology of production and processing of livestock products, 2, 110-116 [in Ukrainian].

14. Ruban, S. Yu., Borshch, O. O., Fedota, O. M., \& Borshh, O. V. (2018). Suchasni metody' selekciyi u tvary`nny`cztvi [Modern methods of selection in animal husbandry. Exterior assessment manual in dairy farming.]. Kyev: $\mathrm{CzP}$ «Kompry`nt» 149 [in Ukrainian].

15. Borshch, O. V. (2014). Osobly`vosti doyinnya koriv na roboty`zovanij ustanovci [Features of milking cows on a robotic installation]. Zbirnyk naukovykh prats Bilotserkivskoho natsionalnoho ahrarnoho universytetu. Seriia: "Tekhnolohiia vyrobnytstva i pererobky produktsii tvarynnytstva» [Collection of scientific works of Bila Tserkva National Agrarian University. Series: "Technology of production and processing of livestock products"]. Bila Tserkva, 2 (112), 131-135 [in Ukrainian].

16. Dikmen, S. J., \& Hansen, S. (2009). Is the temperature-humidity index the best indicator of heat stress in lactating dairy cows in a subtropical environment? Journal of Dairy Science, 92, 109-116. DOI: 10.3168/jds.2008-1370.

17. Menconi, M. E. \& Grohmann, D. (2014). Model integrated of life-cycle costing and dynamic thermal simulation (mild) to evaluate roof insulation materials for existing livestock buildings. Energy and Buildings, 81, 48-58. DOI: 10.1016/j.enbuild.2014.06.005

18. Smith, J. F., Bradford, B. J., Harner, J. P., Potts, J. C., Allen, J. D., Overton, M. W., Ortiz, X. A., \& Collier, R. J. (2016). Short communication: Effect of cross ventilation with or without evaporative pads on core body temperature and resting time of lactating cows. Journal of Dairy Science, 99, 1495-1500. DOI: 10.3168/jds.20159624

19. Gebremedhin, K. G., Wu, B., \& Perano, K. (2016). Modeling conductive cooling for thermally stressed dairy cows. Journal of Thermal Biology, 56, 91-99. DOI:10.1016/ j.jtherbio.2016.01.004

20. Borshch, O. O., Ruban, S. Yu., Gutyj, B. V., Borshch, O. V., Sobolev, O. I., Kosior, L. T., Fedorchenko, M. M., Kirii, A. A., Pivtorak, Y. I., Salamakha, I. Yu., Hordiichuk, N. M., Hordiichuk, L. M., Kamratska, O. I., Denkovich, B. S. (2020). Comfort and cow behavior during periods of intense precipitation. Ukrainian Journal of Ecology, 10(6), 98-102. DOI : 10.15421/2020_265

21. Dikmen, S. J., \& Hansen, S. (2009). Is the temperature-humidity index the best indicator of heat stress in lactating dairy cows in a subtropical environment? Journal of Dairy Science, 92, 109-116. DOI: 10.3168/jds.2008-1370.

22. Moran, D. S., Pandolf, K. B., \& Shapiro Y. (2001). An environmental stress index (ESI) as a substitute for the wet bulb globe temperature (WBGT). Journal of Thermal Biology, 26, 427-431. DOI:10.1016/S0306-4565(01)00055-9

23. Gaughan, J. B., Mader, T. L., Holt, S. M., Hahn, G. L., \& Young, B. A. (2002). Review of current assessment of cattle and microclimate during periods of high heat load. Animal Production of Australia, 24, 77-80.

24. Gaughan, J. B., Mader, T. L., Holt, S. M., \& Lisle, A. (2008). A new heat load index for feedlot cattle. Faculty Papers and Publications in Animal Science, 1(1), 226-234.

25. Vatskyi, V. F. (2005). Alhorytmy biometrii. Metodychni rekomendatsii. [Biometrics algorithms. Guidelines.]. Poltava [in Ukrainian]. 
26. Hulsen, J. (2006). Cow signals. A practical guide for dairy farm management.

\section{СРАВНЕНИЕ РАЗЛИЧНЫХ СИСТЕМ СОДЕРЖАНИЯ КОРОВ В ПЕРИОД ТЕПЛОВОГО СТРЕССА}

Борщ А. А., Борщ А. В. Белоцерковский Национальный аграрный универсиmem

Целью работы было изучить влияние высоких температур на комфортность содержания коров голитинской породы при разных вариантах беспривязного содержания. Изучение влияния высоких температур на комфортность содержания коров проводили в период с 02.07-12.07 2018 в Киевской области. Для проведения исследований было выбрано три хозяйства с беспривязным содержание коров и различными вариантами уровня комфорта животных. Первый вариант - беспривязное содержание в легкосборном помещении. Второй вариант беспривязное содержание в легкосборном помещении с вентиляторами и системой орошения воды. Третий вариант - на выгульно-кормовых площадках с навесами. В течение суточного периода наблюдений определяли основные показатели микроклимата в зоне отдыха (температуру воздуха, относительную влажность, скорость движения ветра), частоту дыхания, оценку тяжести дыхания и индексы тепловой нагрузки. Лучшие показатели среди исследуемых технологий содержания были зафиксированы на ферме с использованием систем орошения и вентилящии. В период наивысшего теплового стресса (12.00-16.00 ч) температура

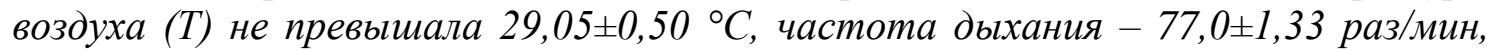

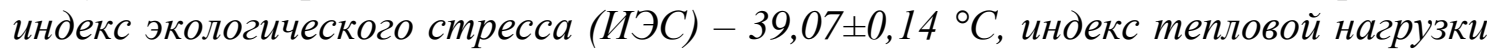
(ИТН) - 73,56士2,48. Самые низкие показатели комфорта содержания были в легкосборном помещении: $T$ - 31,1 $12,24{ }^{\circ} \mathrm{C}$, частота дыхательных движений -

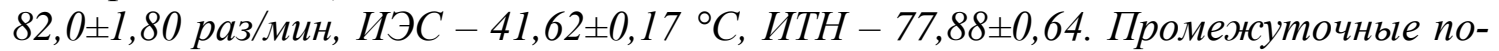
казатели были за содержание на кормовом площадке: $T-30,3 \pm 2,31{ }^{\circ} \mathrm{C}$, частота

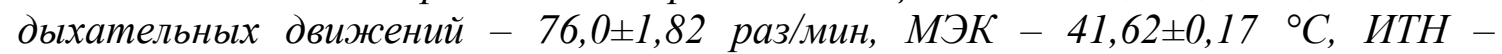
77,42士0,51. Всех вариантов содержания коров повышение температуры до среднесуточных $+27,7^{\circ} \mathrm{C}$ стало значительным стресс-фактором, который существенно повлиял на динамику частоты дыхания, оценку тяжести дыхания, значение ИЭС и ИТН. Установлено, что за содержание коров в помещениях с использованием систем орошения и вентилячии, а такэе на выгульных площуадках показатели температурно-влажностного индекса (ТВИ), частоты и тяжести дыхания в период максимальной температурной нагрузки (12.00-16.00 ч) были ниже, чем за содержания в легкосборном помещении.

Ключевые слова: молочные коровы, технология содержания, температура, тепловой стресс, комфорт, тяжесть дыхания.

\section{COMPARISON OF DIFFERENT HOUSING SYSTEMS FOR COWS DURING HEAT STRESS}

Borshch O. O., Borshch O. V., Bila Tserkva National Agrarian University

The work aimed to study the effect of high temperatures on the comfort of keeping Holstein cows with different options for loose housing. The study of the effect of high temperatures on the comfort of keeping cows was carried out in the period from 02.07-12.07 2018 in the Kyiv region. Three farms were selected with loose cow housing systems and various options for the level of animal comfort. The first option is loose housing in an easy-to-collect room. The second option is loose keeping in an easily col- 
lectible room with fans and a water irrigation system. The third option is for walking and feeding grounds with sheds. During the daily observation period, the main indicators of the microclimate in the recreation area (air temperature, relative humidity, wind speed), respiration rate, assessment of the severity of respiration and heat load indices were determined. The best performance among the studied housing technologies was recorded on a farm using irrigation and ventilation systems. During the period of the highest heat stress $(12.00-16.00 \mathrm{~h})$, the air temperature $(T)$ did not exceed $29.05 \pm 0.50$ ${ }^{\circ} \mathrm{C}$, the respiratory rate $-77.0 \pm 1.33$ times/mins, the environmental stress index (ESI) $39.07 \pm 0.14^{\circ} \mathrm{C}$, the heat load index (HLI) - 73.56 \pm 2.48 . The lowest indices of the comfort of keeping were in an easily assembled room: $T-31.1 \pm 2.24{ }^{\circ} \mathrm{C}$, respiratory rate $82.0 \pm 1.80$ times $/ \mathrm{min}, \mathrm{ESI}-41.62 \pm 0.17{ }^{\circ} \mathrm{C}, \mathrm{HLI}-77.88 \pm 0.64$. Intermediate indicators were for the content on the stern area: $T-30.3 \pm 2.31^{\circ} \mathrm{C}$, respiratory rate $-76.0 \pm 1.82$ times/mins, ESI - 41.62 $\pm 0.17^{\circ} \mathrm{C}, \mathrm{HLI}-77.42 \pm 0.51$. In all options for keeping cows, an increase in temperature to an average daily $+27.7^{\circ} \mathrm{C}$ became a significant stress factor that significantly influenced the dynamics of the respiration rate, the assessment of the severity of respiration, the value of ESI and HLI. It was found that for keeping cows in buildings using irrigation and ventilation systems, as well as on walking grounds, the indicators of the temperature-humidity index (THI), frequency and severity of respiration during the period of maximum temperature load (12.00-16.00 h) were lower than those for keeping in an easily assembled room.

Keywords: dairy cows, keeping technology, temperature, heat stress, comfort, breathing heaviness.

УДК 636.2.022

DOI 10.32900/2312-8402-2021-125-91-106

\title{
НЕКОТОРЫЕ АСПЕКТЫ ОРГАНИЗАЦИИ СЕЛЬСКО- ХОЗЯЙСТВЕННЫХ ВЫСТАВОК ПЛЕМЕННЫХ КОРОВ (ОГЛЯДОВА)
}

\author{
Гончаренко И. В., Д. с.-х. н., професор \\ Национальный университет биоресурсов и природопользования Украины \\ Гришко С. И., управляющий фермой отделения «Дударков» \\ ГП «Чайка», Бориспольского р-на Киевской обл.
}

Изложено информащию о проведении выставок-аукционов племенных коров на Международном и региональном уровне. Целью всех этих выставок является обмен практическим опытом работы по разведению крупного рогатого скота разных пород, пропаганда селекиионных достижений лучиих хозяйств, выявление коров-чемпионок по комплексной оценке.

Обобщен организационный опыт международных выставках коров в зарубежных странах. На примере Королевской выставки "The Royal» (Торонто, штат Онтарио, Канада), раскрыты некоторые особенности подготовки коров к выставке или тонкости коровьего стайлинга.

Одним из основных тематических направлений Международной агропромышленной выставки "АГРО» (Киев) является экспозиция Animal EX - демонстрация и аукиион племенных животных. Постоянным участником коровьих выставок является государственное предприятие «Чайка» Бориспольского района, Киевской области. За десятилетний период (2011-2019 г2.) по выставочным ко- 